\title{
Dunia dan Dīn (Agama) di Tengah Arus Globalisasi
}

\author{
Oleh: \\ Rahmat Hidayat \\ Universitas Islam Negeri Raden Fatah \\ rahmathidayat uin@radenfatah.ac.id
}

\begin{abstract}
Globalization as a process or historical necessity is able to affect all lines of human life. Its rapid development must be addressed proportionally, especially for Muslims who have a global teaching order, which remains relevant in line with the times. Today's globalization tends towards worldly affairs which are loaded with elements of modernity, whose impact can be felt not only from economic, scientific and technological aspects, but other aspects such as culture, fun, fashion, social, lifestyle (life style), education, politics, thought and religion. This paper aims to map out the area of globalization, whether in the realm of the world or religion and how does it impact the globalization of religion?
\end{abstract}

Keywords: globalization, world, religion

\section{Abstrak}

Globalisasi sebagai sebuah proses atau keharusan sejarahmampu mempengaruhi segala lini kehidupan manusia. Perkembangannya yang begitu pesat mesti disikapi secara proporsional, terlebih bagi umat Islam yang memiliki tatanan ajaran global, yang tetap relevan seiring dengan berkembangnya zaman. Globalisasi yang berlangsung dewasa ini cenderung kapada urusan duniawi yang sarat dengan unsurunsur modernitas, yang dampaknya dapat dirasakan tidak hanya dilihatdari aspek ekonomi, sains dan teknologi sajamelainkan aspek-aspek lainnya seperti budaya, fun, fashion, sosial, gaya hidup (life style), pendidikan, politik, pemikiran dan Agama.Tulisan ini bertujuan untuk memetakan di mana wilayah globalisasi, apakah ke ranah dunia atau Agama dan bagaimana dampak globalisasi Agama?

Kata Kunci: globalisasi, dunia, agama

\section{A. Pendahuluan}

Di akhir-akhir tahun 1980-an, istilah globalisasi tidak begitu familiar dalam berbagai bahasa di belahan dunia.Diksi ini di tahun-tahun tersebut hanya digunakan untuk dunia perbisnisan dan ilmu-ilmu yang berkaitan dengan sosial lainnya. ${ }^{1} \mathrm{Namun}$ di tahun berikutnya, sekitar tahun 1990-an, isu seputar globalisasi sudah semakin mendunia dan marak.Karenanya era ini sering disebut dengan era globalisasi (the

\footnotetext{
${ }^{1}$ Peter Beyer (ed.), Religion, Globalization, and Culture (Leiden: Koninklijke Brill: 2007), 1.
} 
age of globalization). ${ }^{2}$ Maraknya diskursus seputar globalisasi pada masa tersebut menurut Abuddin Nata, tidak terlepas dari pengaruh perekonomian dunia, apalagi era pasar bebas (free trade) yang tidak lagi dibatasi oleh sekat-sekat geografis, budaya dan ideologi politik sebuah negara. Meski globalisasi beranjak dari persoalan ekonomi, namun sangat berkaitan juga dengan persoalan-persoalan lainnya, seperti sosial, budaya, agama, politik, pendidikan, life style (gaya hidup), sains dan teknologi. $^{3}$

Globalisasi dianggap sebagai sebuah proses sejarah dan proyek ekonomi tentu dapat mempengaruhi struktur sosial pada tingkat kesejahteraan manusia. Tersedianya informasi yang dapat diakses secara cepat, massif dan ekonomis merupakan dampak positif dari globalisasi, sehingga kehidupan manusia dapat terjalin melalui jaringan komunikasi dan transaksi global.Dunia terasa semakin kecil karena ditopang oleh teknologi informasi dan komunikasi yang begitu canggih.Peristiwa yang baru terjadi dapat terdeteksi dan diketahui di berbagai belahan dunia lainnya dengan sangat cepat.Oleh karen itu, wajar jika Marshall McLuhan mengibaratkan dunia ini sebagai global village (desa global). ${ }^{4}$ Di samping hal-hal positif, ada pula dampak negatif dari globalisasi,seperti kesenjangan dan ketimpangan ekonomi antara yang miskin dan yang kaya, lingkungan dan alam semakin rusak akibat eksploitasi dan eksplorasi yang berlebihan terhadap sumber daya alam, persaingan hidup sosial, budaya, agama, politik, bisnis, dan lain-lain semakin meluas. ${ }^{5}$

Memang globalisasi sudah menjadi sebuah keharusan sejarah yang mau tidak mau pasti akan terjadi dan mesti disikapi secara bijak, lebih-lebih bagi umat Islam yang memiliki tatanan ajaran global yang sangat luhur dan tetap relevan seiring dengan perkembangan zaman. Semua yang ada di dunia ini akan berubah, tidak ada yang abadi, kecuali perubahan itu sendiri, demikian kata filosof Hieraklitus. ${ }^{6}$ Lajunya perkembangan zaman yang begitu pesat membuat hampir semua tatanan dalam kehidupan bermasyarakat berpotensi dirombak di era ini.Globalisasi yang berlangsung dewasa ini pun menampilkan sumber dan watak yang

\footnotetext{
${ }^{2}$ Khusnul Khatimah, Islam dan Globalisasi: Sebuah Pandangan Tentang Universalitas Islam, di dalam Komunika (Jurnal Dakwah dan Komunikasi), vol. 3, No. 1, Januari-Juni 2009, hal. 1.

${ }^{3}$ Abudin Nata, Kapita Selekta Pendidikan Islam (Bandung: Angkasa, 2003), 182-3.

${ }^{4}$ Mukhtar Hadi, Agama di Tengah Arus Globalisasi: Sebuah Pendekatan Multikultural (STAIN Jurai Siwo Metro), 4.

${ }^{5}$ Faisal Afif, Agama dan Globalisasi, Rangkaian Kolom Kluster I, 2012, Binus University, hal. 1.

${ }^{6}$ Poedjawijatna, Pembimbing ke Arah Alam Filsafat (Jakarta: PT. Pembangunan, 1980), 20.
} 
berbeda.Peradaban Barat adalah kiblat dari era ini dan memegang kendali serta mendominasi dalam berbagai lini kehidupan masyarakat dunia pada umumnya.Nilainilai dan pandangan hidup (worldview) Barat-modern pun tidak dapat dihindari masuk dan berkembang dalam kehidupan bermasyarakat melalui globalisasi. ${ }^{7}$

Percaturan globalisasi setidaknya telah dimulai sejak adanya perjalanan yang dilakukan oleh para pedagang untuk berkeliling dari negaranya ke seluruh penjuru negara lain. Ketika para pedagang Arab melakukan perjalanan perdagangan ke berbagai negara di Asia Tenggara, termasuk ke Indonesia, dan begitu pula orang Eropa yang melakukan ekspansinya dalam artian hal yang bersifat kolonialisme, sesungguhnya globalisasi telah berjalan. ${ }^{8}$ Boleh dikatakan bahwa globalisasi adalah suatu proses westernisasi dan kolonialisasi. Oleh karena itu, perkembangan dan proses globalisasi tidak perlu dihadapi dengan sikap menutup diri secara ekstrim, apalagi mempunyai sikap anti terhadapnya sehingga menolak segala unsur yang berbau globalisasi. Terdapat rambu-rambu yang mesti diketahui ketika berinteraksi dunia globalisasi.Pengetahuan dan wawasan manusia mengenai rambu-rambu tersebut dapat mengantarnya dalam pengharmonisasian antara urusan dunia yang sarat dengan adanya intervensi globalisasi dengan urusan Agamanya.Urusan duniawi merupakan interaksi manusia dengan sesamanya dan lingkungannya, sedangkan ukhrawi (Agama) adalah interaksi manusia dengan Tuhannya. Melalui artikel ini penulis akan membincangkan mengenai globalisasi, di wilayah manakah ia berperan, Dunia atau Agama? dan bagaimana jika globalisasi mempengaruhi aspekAgama?

\section{B. Domain Globalisasi: Dunia atau Dīn (Agama)?}

Globalisasi merupakan terminologi baru namun eksistensinya telah ada sejak lama.Pada abad $19 \mathrm{M}$ gejala ini telah muncul sebagai rekaan demokrasi sosial gaya lama. ${ }^{9}$ Jika globalisasi di abad 19 lebih cenderung pada aspek penguasaan perdagangan melalui pasar dan perdagangan secara fisik, namun beda polanya dengan globalisasi yang terjadi pada abad 21. Pada abad ini, instrumen politik, budaya dan teknologi sudah dikerahkan.Para pemilik modal dari negara-negara maju

\footnotetext{
${ }^{7}$ Abudin Nata, Kapita Selekta Pendidikan Islam, 182-3.

${ }^{8}$ Mukhtar Hadi, Agama di Tengah Arus Globalisasi, 4.

${ }^{9}$ Anthony Giddens, Jalan Ketiga: Pembaharuan Demokrasi Sosial (Terjemahan), (Jakarta: Gramedia, 2000), $32-33$.
} 
tidak perlu bersusah payahdan berlama-lama di perjalanan untuk melakukan transaksi perdagangan.Melalui kerjasama kelompok ekspansi pasar dapat dilakukan.Kerjasama pemasaran diorganisir dan berdasarkan kesepakatan politis.Negara yang lobi politisnya kuat lebih berpotensi mendapat keuntungan dan diprioritaskan daripada negara yang lemah lobinya. ${ }^{10}$

Betapapun pengaruh globalisasi sangat cepat dan fundamental karena mengacak-acak pola tatanan lama kemudian mendorong munculnya tatanan baru akibat kemajuan teknologi informasi dan komunikasi.Sekarang pengaruh globalisasi amat nyata.Itu sebabnya Din Syamsuddin dalam khutbah Idul Fitrinya tahun 1433/2012 mengingatkan hal ini sebagai ancaman serius bagi eksistensi bangsa.Menurutnya, globalisasi berpotensimembuat bangsa kita terjebak pada permisivisme budaya.Itulah yang terjadi pada perkembangan budaya bangsa saat ini yang terkesan semakin hedonistik. ${ }^{11}$

Oleh karena itu, saat ini globalisasi hampir mempengaruhi semua lini kehidupan yang ada pada masyarakat.Budaya-budaya dunia saling mempengaruhi dan berbagi.Hal ini merupakan keniscayaan yang tidak dapat dihindari, karenanya yang harus dilakukan adalah meresponnya, bukan malah menghindar.

Globalisasi erat kaitannya dengan hubungan duniawi.Perlu diketahui bahwa diksi duniasebagaimana dijelaskan oleh Ibn Manzhūr,berasal dari akar kata danāyadnū yang berarti qaruba (dekat).la dijadikan sebagai sesuatu yang dekat. Itu sebabya dikatakan dunia karena ia dekat, dimana antonimnya adalah akhirat yang bermakna jauh. ${ }^{12}$ Terma dunia menurut Al-Rāghib, mengandung berbagai macam arti, di antaranya paling kecil (lawan dari paling besar), paling hina (lawan dari baik), paling dekat (lawan dari paling jauh) dan paling awal (lawan dari paling akhir), dan lain-lain. ${ }^{13}$ Demikian juga dengan M. Fuad 'Abd Al-Bāqīyang memaknai dunia secara bahasa dengan dekat, rendah, hina, sempit, lemah, dan bawah. ${ }^{14}$

Di dalam al-Qur'an, makna-makna yang terkandung dari kata dunia seperti disebut di atas banyak ditemukan.Seperti misalnyaQS.Al-Anfāl (8): 42; QS. Al-

\footnotetext{
${ }^{10}$ Tajuddin Noer Effendi, Globalisasi dan Kemiskinan, dalam Jurnal Ilmu Sosial dan Ilmu Politik, Vol. 7, No. 2, Nopember 2003, hal. 144.

${ }^{11}$ Syamsul Kurniawan, Globalisasi, Pendidikan Karakter dan Kearifan Lokal yang Hybrid Islam Pada Orang Melayu Kalimantan Barat, Jurnal Penelitian, Vol. 12, No. 2, 2018, 321.

${ }^{12}$ Ibn Manzhūr, Lisān al- 'Arab, ed. Abdullah Ali Al-Kab̄̄r, dkk, (Cairo: Maktabah Dār al-Ma‘ārif, tanpa tahun), Bab Danā, J. 2, hal. 1435.

${ }^{13}$ Al-Rāghib Al-Iṣfahānī, Mufradāt li Alfāzh al-Qur'ān, Bab Danā, hal. 318-319.

${ }^{14}$ M. Fuad 'Abdul Bāqī,al-Mu 'jam al-Mufahras li Alfazh al-Qur'ān, (Cairo: Dār al- Hadīts, 1364 H),261-262.
} 
Shāffät(37), 6; dan QS. Al-Mulk (67): 5dimana kata-kata dunia diartikan dengan dekat. QS. Al-Mujādalah(58): 7; dan QS. Al-Muzzammil (73): 20 diartikan dengan sesuatu yang kurang (adnā).Danyang mengandung arti rendahtercermin di dalam QS.Al-Baqarah (2): 61; dan QS. Al-A'rāf (7): 169.

Irsyadunnas menyatakan, ada tiga persepsi manusia memandang dunia: ${ }^{15}$

\section{Pandangan Monisme}

Monisme dapat dikategorikan seperti orang musyrik.Mengenai kehidupan dunia, orang musyrik berpandangan:

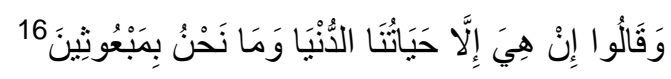

Artinya: dan tentu mereka akan mengatakan: hidup hanyalah kehidupan kita di dunia ini saja dan kita sekali-sekali tidak akan dibangkitkan".

Ayat di atas dipahami bahwa orang musyrik mengakui kehidupan dunia adalah segala-galanya.Keingkaran mereka terhadap hari kiamat dan hari kebangkitan sama halnnya dengan keingkaran terhadap kekuasaan Allah Swt pada alam semesta.

2. Pandangan Pragmatisme

Pragmatisme dalam hal ini adalah orang munafik.Pandangan orang munafiq terhadap kehidupan dunia berbeda dengan kaum monisme.Orang munafiq hanya memikirkan kehidupan duniawi dan tidak begitu memedulikan kehidupan ukhrawi.Padahal keyakinan pada hari akhirat dalam diri mereka itu ada.Hal yang demikian dapat dilihat dalam firman Allah Swt:

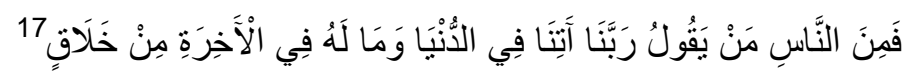

Artinya: Maka diantara manusia ada orang yang berkata: ya Tuhan kami berikanlah kami kehidupan dunia. Dan tiadalah baginya bahagian (yang menyenangkan) di akhirat.

Orang munafiq pada dasarnya beriman kepada Tuhan, Rasul dan hari kiamat.Mereka percaya kehidupan dunia dan akhirat itu ada hubungannya, hanya saja tidak memedulikan kehidupan akhirat.Baginya kehidupan dunia lebih utama dan

\footnotetext{
${ }^{15}$ Irsyadunnas, Konsep Islam Tentang Dunia dan Dinamika Kehidupan, dalam Jurnal Penelitian Agama, Vol. XIV, No. 3, 2005.

${ }^{16}$ QS. Al-An' $\bar{a} m, 6: 29$.

${ }^{17}$ QS. Al-Baqarah(2): 200.
} 
nyata.Mereka selalu meminta agar diberikan rezeki dalam kehidupan dunia.Dari sini tampak pemikiran mereka yang pragmatis karena selalu meminta agar kebutuhan materi terpenuhi.

\section{Pandangan Progresif}

Berbeda dari dua pandangan di atas, mukmin sejati meyakini adanyakehidupan setelah mati.Kebaikan dunia dan akhirat dijadikan sebagai tujuan.Karena itulah Allah berfirman:

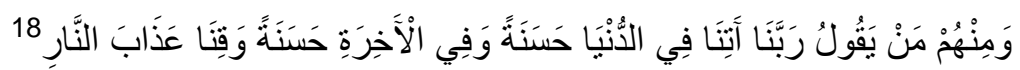

Artinya: Dan di antara mereka ada orang yang berdo'a: ya Tuhan kami berilah kami kebaikan di dunia dan kebaikan akhirat dan periharalah kami dari siksa api neraka.

Hasanah (kebaikan) dalam hal inimengandung makna yang berbagai, seperti kesehatan, rumah tangga yang tenang, pasangan yang baik (shaleh/shalehah), banyak rezeki, ilmu yang bermanfaat, punya kendaraan, dan lain-lain. ${ }^{19}$ Sedangkan nikmat kebaikan yang paling besar di akhirat adalah masuk syurga disertai dengan ketenangan dan terhindar dari ketakutan. ${ }^{20}$

Di sinilah perbedaan pandangan hidup antara monisme dan pragmatisme dengan progresif.Jika orang musyrik memandang kehidupan dunia hanya sekali dan orang munafik kurang memedulikan kehidupan akhirat meskipun mengakuinya, namun orang mukmin sangat meyakini kedua-duanya.

Di samping istilah globalisasi dan dunia di atas, ditemukan bahwa istilah duniaseakar juga dengan katadīn (Agama).Dīnmenurut Al-Fairūzābādī mengandung berbagaimakna, sepertibalasan,Islam,adat atau kebiasaan,ibadah, ketaatan, perhitungan, kerendahan hati,mengesakan Tuhan,peraturan,kekuasaan, perjalanan hidup, hutang, agama, dan segala bentuk penghambaan kepada Allah Swt. ${ }^{21}$

Makna dīn selama ini dipahami dan diartikan sebatas Agama.Padahal jikadiamati dari kandungan makna di atas tidaklah demikian.Konsep yang terkandung di dalam makna dīnmenurut al-Attas,meliputiempat aspek yaitu indebtedness (dalam

\footnotetext{
${ }^{18}$ QS. Al-Baqarah (2): 201.

${ }^{19}$ Ibn Katsīr, Tafsīr Ibn Katsīr, ed. Sāmī bin Muhammad Salāmah (Cairo: Dār Thayyibah, 1999), J. 2, 262.

${ }^{20}$ Ibid.

${ }^{21}$ Al-Fairūzābādī, Al-Qāmus Al-Muhịt, hal.1546.
} 
keadaan berhutang), submissiveness(penyerahan diri), judicious power(kuasa peradilan) dan natural inclination and tendency(kecenderungan alami). ${ }^{22}$

Keber-agamaanadalah kewajiban manusia akankeberhutangannya. Keberagamaanadalahsifat alamiah manusiayang ada dalam dirinya.Naluri keberagamaan tentu mengarah kepada aspek spiritual,meskipun dalam aktivitas keseharianditempuh dan terdapat keraguan dalam diri manusia kepada Tuhan.Namun pada hakikatnya, naluri keberagamaan sampai kapan pun tidak dapat dihilangkan dari dalam diri manusia.Sifat alamiah yang mempengaruhi keberagamaan seseorang dengan menghambakan dirinya kepada Tuhan, secara tidak langsung telah mengakui kuasa peradilan, yang dalam hal ini adalah kuasa Allah Swt sebagai al-Dayyān.Menyadari bahwa Allah Swt adalah Penguasa sekaligus Berkuasa untuk mengendalikan diri manusia dan alam raya.Allah Swt adalah Pembuat Perhitungan, Raja pada hari peradilan dan pembalasan (aljazāíwaal-mukāfa'ah). ${ }^{23}$ Oleh karena itu, kewujudan manusia di pentas muka bumi,yang tidak akan pernah mampu menciptakan penglihatannya, pendengarannya, panca inderanya apalagi membiarkan dirinya bergerak sendiri dengan kesadaran, itu semuaadalah hutang terbesar yang dimilikinya.Hutang tersebut sampai kapan pun tidak dapat dibayar kecuali jika ia menyerahkan dirinya kepada Tuhan (aslama) ${ }^{24}$. Aslama adalah penyerahan diri yang sesungguhnya secara totalitas,bukan penyerahan diri yang bersumber dari produk budaya maupun pengalaman hidup manusia sebagaimana ditemukan di dalam kepercayaan semua Agama pada umumnya.Sifat penyerahan diri seperti ini sudah terintegrasi dalam konsep dīn.

Dīn sebagaimana dijelaskan di atas adalahseakar dengan kata dunia.Oleh karena itu dīn hanya diaplikasikan di dunia, dan bukan di tempat yang lain. Dikarenakan dunia menempati ruang (bumi/globe) dan waktu (sekarang), maka dapat disimpulkan bahwa dunia sangat erat kaitannya dengan globalisasi.Sedangkan dīntidaklah demikian.Peter Beyer dan Lori Beaman di dalam Religion, Globalization,

\footnotetext{
${ }^{22}$ SMN al-Attas, Prolegomena to The Metaphysic of Islam (Kuala Lumpur: ISTAC, 1995), 41-2.

${ }^{23}$ Makna yang terkandung di dalam perkataan dīn selain dijelaskan tadi, ia dapat pula diartikan sebagai $a l-j a z \bar{a}{ }^{\text {, }}$ (pembalasan).Oleh karena itu, yaum al-dīn adalah yaum al-jazā' yaitu hari pembalasan. Ibn Manzūur, Lisān al'Arab, J. 2, 1468; dan dapat dilihat pula al-Attas, Prolegomena, khususnya pada pembahasan Islam: The Concept of Religionand The Foundation of Ethics and Morality.

${ }^{24}$ Lihat misalnya firman Allah SWT di dalam QS. Al-Nisa', 4: 125; QS. Ali 'Imran, 3: 83, 85 dan 19. Din yang dimaksudkan tidak lain adalah Islam. Tidak ada keraguan bahwa ada bentuk-bentuk din yang lain, tetapi ada satu yang terbaik yaitu yang menggambarkan penyerahan diri yang sejati, benar dan secara totalitas (istislam) hanya kepada Allah SWT. Penyerahan diri tersebut tidak bermaksud hilangnya kebebasan bagi seseorang, karena kebebasan sesungguhnya adalah bertindak sesuai dengan yang dituntut oleh hakikat sebenarnya dari dirinya, lihat SMN al-Attas, Islam and Secularism (Kuala Lumpur: ISTAC, 1993), 62-66.
} 
and Culture mengatakan, Agama agaknya tidaklah begitu terbukabagi globalisasi, karena ia bersifatexclusive(tersendiri atau sesuatu yang terasing).Globalisasi tidak dapat masuk ke ranah Agama, karena Agama tereksklusi dari globalisasi. Dalam artian ia tidak boleh terkontaminasi oleh globalisasi itu sendiri:

Religion does not very often seem to be about globalization nor globalization about religion...., religion it seems, is somehow "outside" looking at globalization as problem or potential. ${ }^{25}$

Lagi pula, globalisasiseperti yang dikatakan oleh George M. Thomas,berpotensi menjadikan hidup semakin ruwet, manusia akhirnyasangat bergantung pada urusan duniawinya danmengembalikan proses-proses serta mekanisme yang ada di dalamnya(globalization refers to the increasing complexity and interdependence of the world as a whole and to the processes and mechanisms involved). ${ }^{26}$

Jika globalisasi disikapi secara berlebihan dantotalitas terhadap urusan duniawi,tidak menutup kemungkinan akanmelahirkan manusia yang berbudaya konsumerisme, hedonisme, materialisme dan narkotisme. Budaya-budaya seperti inilah tegas Adian Husaini yangdijadikan sebagai temayang menarik dalam kajian globalisasi.Budaya-budaya tadi ditandai oleh hegemoni food (makanan), fun (hiburan), fashion (mode) dan thought (pemikrian).Oleh karena itu, globalisasi adalah perkara yang kompleks dan sulit dihindari oleh umat manusia yang semakin terintegrasi dalam perkembangan alat-alat komunikasi dan transportasi modern.Dengan demikian, globalisasi semakin mengarah kepada bentuk imperialisme budaya (cultural imperialism) Barat terhadap budaya-budaya lain. ${ }^{27}$

Dari penjelasan di atas jelas bahwa globalisasi sarat dengan urusan duniawi.Pertanyaannya adalah bagaimana dengan urusan Agama?apakahkepercayaan-kepercayaan di dalam Agama dapat juga terglobalisasi dan berevolusi seiring dengan perkembangan hidup di dunia?Pada dasarnya hal-hal yang bersifat pokok atau dasar agama (ușūli $\left.{ }^{28}\right)$ tidak dapat diintervensi oleh

\footnotetext{
${ }^{25}$ Religion, Globalization, and Culture, 1.

${ }^{26}$ George M. Thomas, The Culture and Religious Character of World Society, di dalam Religion, Globalization, and Culture, 35.

${ }^{27}$ Adian Husaini, Wajah Peradaban Barat: Dari Hegemoni Kristen ke Dominasi Sekular-Liberal (Jakarta: Gema Insani, 2014), 20.

${ }^{28}$ Seperti yang tercermin di dalam rukun Iman dan Islam.Rukun Iman mencakup keimanan kepada Allah SWT, para MalaikatNya, kitab-kitabNya, para RasulNya, hari akhir, Qadha dan Qadar. Sedangkan rukun Islam mencakup syahadat (kesaksian akan tiada Tuhan selain Allah SWT dan Rasulullah SWT adalah utusanNya yang terakhir), mendirikan shalat, menunaikan zakat, puasa di bulan Ramadhan dan berhaji ke Mekkah bagi yang mampu.
} 
globalisasi.Natsir dalam Kebudayaan Islam mengemukakan bahwa perkara shalat, puasa, zakat dan yang semacamnya itu masuk ke dalam wilayah dīn.Perkara seperti ini harus dikembalikan kepada Rasulullah Saw dan diterima apa adanya tanpa adanya intervensi manusia dalam menentukan kadarnya. Pengamalannya persis sebagaimana yang ditetapkan oleh syāri yaituAllah Swt. Manusia tidak mempunyai kapasitas untuk mengubah, menambah dan mengurangi. Di bidang ibadah ini,semua terlarang kecuali yang telah diperintahkan dan ditetapkan. ${ }^{29}$

Di samping itu,ada juga perintah Agama yang maknanya dapat dirasionalkan (ma'qūl),yang nalar manusia tidak dilarang untuk ikut andil, sehingga keteranganketerangan Agama cukup menunjukkan illat atau sebab-sebabnya saja.Perintah yang semacam ini dapat diketahui dari perintah menutup aurat, perintah berbakti kepada orang tua dan lain-lain.Meskipun sumbernya berasal dari Agama, akan tetapi cara pelaksanaannya tidak ditetapkan dan tidak ditentukan oleh Agama. Tata caranya dikembalikan kepada manusia dengan syarat bisa mencapai tujuan yang dimaksud sesuai dengan keadaan "dunia" atau zaman seseorang masingmasing.Esensi dari perintahnya itusebenarnya bersifat dīnī yaitu bersumber dari perintah Agama, sedangkan caradan praktek pengamalannya bersifat duniawi. ${ }^{30}$

Ini artinya perintah-perintah di luar Agama seperti tadi banyak macamnya dan tidak terhitung banyaknya urusan-urusan yang tidak diatur oleh Agama.Hal yang demikian membuat manusia bebas untuk mengaturnya sendiri asalkan tetap menjaga batasan-batasan dan larangan-larangan Agama supaya tidak dilanggar.Dalam urusan keduniaan akal mempunyai ruang gerak yang amat luas, karenanyadalam urusan ini semua boleh kecuali yang terlarang.Sedangkandalam urusan keagamaan (dīnî), akal terbatas ruang geraknya, oleh karena itu semua terlarang kecuali yang diperintahkan.Globalisasi yang erat kaitannya dengan dunia modern lebih tepat masuk ke wilayah dunia yang kita diperbolehkan menggunakan akal untuk memahami dan menyikapinya.la tidak dapat dimasukkan ke wilayah Agama, karena Agama tidak diperkenankan menggunakan nalar untuk merubah ketentuan-ketentuan yang telah ditetapkan.

Terdapat perintah untuk menjaga kebersihan.Rasulullah Saw memerintahkan untuk membersihkan gigi.Beliau tidak menetapkan dengan apa dan bagaimana cara

\footnotetext{
${ }^{29}$ M. Natsir, Kebudayaan Islam dalam Perspektif Sejarah, ed. Endang Saifuddin Anshari, (Jakarta: Girimukti Pasaka, 1998), 249.

${ }^{30} \mathrm{Ibid} ., 250$
} 
membersihkannya.Namunsekarang, terdapat golongan yang anti terhadap globalisasi atau kemoderenan yangtidak mau memakai pasta gigi kecuali hanya memakai akar kayu(siwak) saja, dengan alasan bahwacarayang seperti itutelah dipraktekkan oleh Rasulullah Saw dan para Sahabat beliau.Pun begitu juga dengan alat transportasi yang digunakan oleh Rasulullah Saw di zaman dahulu seperti unta, kuda dan seumpamanya.Cara-cara sepertiyang disebut tadi, tidak dapat dimasukkan ke dalamranah Agama karena iabukan termasuk wilayah ușūlī. Oleh karena itu, dapat disimpulkan bahwa dalam urusan-urusan dunia, cara-cara dan bagaimana mengerjakannya telah diserahkan kepada manusiaasalkan yang dituju dan yang menjadi pokok dari perintah dapat dicapai sehingga memudahkan mereka.

Di dalam Islam, penggunaan akal (nalar) dalam menafsirkan ajaran-ajaran keagamaan amat penting.Itu sebabnya Rasulullah Saw menyatakan, Agama (Islam) adalah akal, tidak dianggap beragama seseorang yang tidak menggunakan akalnya?Tanpa bimbingan syari'at, akal tidak dapat menentukan dan menetapkan kebenaran.Oleh sebab itu,mengenai urusan Agama terdapat praktik-praktik yang bersifatta'abbudi (ibadah) yang tidak mampu dicerna dan dijangkau oleh akal dan nalar.Keyakinan keagamaan harus diterima meskipuniatidak dimengerti oleh akal, demikian tegas Qurasih Shihab. Dari sini dapat diketahui bahwa wilayah akal, dunia, modernitas dan globalisasi adalah terbatas pada alam fisika.Sedangkan Agama dan hati wilayahnya adalah alam metafisika. ${ }^{31}$ Dunia dan modernitas berbicara tentang wujud yang tampak dan terjangkau oleh hal-hal yang bersifat lahir dan nyata bagi pandangan manusia, sedangkan Agama berbicara tentang wujud yang tidak tampak oleh pandangan mata saat ini.

\section{Dampak Globalisasi Agama}

Usaha untuk bersikap akomodatif yang berlebihan terhadap globalisasi lebihlebih dalam hal keberagamaan,akan menjadikan Agama berpotensi terbaratkan.Hal ini dapat diasumsikan bahwa manusia sedang berkembang menuju bentuk kehidupan yang seragam yaitu berpola Barat,meskipun tahapan-tahapan yang dicapai masing-masing masyarakat berbeda-beda di suatu tempat. Namun pada intinya semuanya akanmenuju kepada pola yang sama yaitu berpola modern. Dengan kata lain modernisme yang dinahkodai oleh sistem global adalah muara dari

\footnotetext{
${ }^{31}$ M. Quraish Shihab, Logika Agama: Kedudukan Wahyu dan Batas-Batas Akal dalam Islam, khususnya dalam pembahasan Islam dan Akal, (Jakarta: Lentera Hati, 2005), 88-9 dan 93.
} 
perjalanan hidup manusia.Pola seperti ini sebenarnya berasal dari zaman pencerahan Eropa, yang diwarnai kritik hampir tak terbatas terhadap tradisi dan agama disertai penilaian yang serba positif akan keberhasilan pemikiran pencerahan (aufklarung) dan optimisme yang luar biasa akan masa depan manusia yang dikendalikan oleh otoritas nalar. ${ }^{32}$

Gobalisasi bukan hanya berlangsung padaatau mempengaruhi aspek ekonomi, politik, budaya, konsumerisme, hedonisme, fantasi, gaya hidup dan fashion saja, tetapi juga mempengaruhi cara berpikir manusia (thought), sehingga cara berpikir kaum Muslim khususnya pun diatur. Bahkan yang lebih ironi, cara kaum Muslim beriman kepada Tuhannya, menyembahnya dan juga memahami kitab sucinya pun tak luput dari hegemoni. Oleh sebab itu,Agama yang terglobalisasi, akan berupaya mendelegitimasi kitab suci, khusunya al-Qur'an.Fenomena mengkritik al-Qur'an atau setidaknya menyatakannya sebagai kitab suci yang bias gender sepertinya menjadi suatu kebanggaan, bahkan itu terjadi di kalangan sarjana Muslim sendiri.Metode penafsiran yang lagi marak saat ini seperti hermeneutika di kalangan akademisi Islam juga tidak terlepas dari hegemoni pemikiran Barat dalam studi Islam.Jika kebenaran Agama sudah tidak diyakini lagi, maka akal manusia dan hawa nafsunya yang dijadikan pegangan.Tidak ada standar kebenaran.Mereka anggap bahwa arus nilai serba relatif dan bersifat temporal.Kebenaran bergantung pada kesepakatan.Jika masyarakat sepakat bahwa pelacuran, homoseksual, perjudian dan minuman keras adalah sesuatu yang halal, baik dan diperbolehkan maka itu dinilai sebagai sebuah kebenaran. ${ }^{33}$

Di samping itu pula, Agama yang terglobalisasi tegas Adian,akan melahirkan sikap mengimani konseppluralisme Agama (religious pluralism). Pluralisme adalah suatu paham yang menganggap semua Agama adalah benar, karena ia menujukepada Satu keparipurnaan (the Ultimate) yang sama walaupun jalan yang ditempuhnya berbeda-beda. Meskipun istilah "pluralisme Agama" lahir dan dikembangkan di Barat, tetapi istilah tersebut mulanya tidak dikenal dalam teologi resmi Gereja.Sebagaimana istilah sekularisme, yang pada mulanya tidak dikenal atau asing bahkan dimusuhi oleh kaum Kristen, kemudian diterima dan dicarikan legitimasinya dalam Bible.Penyebaran paham ini merupakan bagian dari upaya Barat mengglobalisasikan nilai-nilainya dan meneguhkan hegemoninya atau sebagai

\footnotetext{
${ }^{32}$ Mukhtar Hadi,Agama di Tengah Arus Globalisasi........, 9-10.

${ }^{33}$ Adian Husaini, Wajah Peradaban Barat, 17 dan 289.
} 
upaya kalangan misionaris Kristen untuk melemahkan keyakinan umat Islam.Pluralisme sebagaimana sekularisme adalah sejenis senjata pemusnah massal terhadap keyakinan fundamental agama-agama. Jika perbedaan konsepsi dan sejarah antara teologi Kristen dengan Islam diketahui dan dipahami oleh kaum Muslim, makamereka tidak perlu latah menerima paham tersebut, karenadisinyalirakan membunuh agama dan konsep teologi Islamitusendiri. Pluralisme dianggap sebagai sebuah agama baru dengan konsep teologi baru yang pada hakikatnya membubarkan agama-agama yang ada. ${ }^{34}$

Dengan demikian, agama yang terbuai dengan arus globalisasi menjadikan keabsolutan nilai-nilai, ajaran-ajaran dan kebenaran yang bersumber dari Agama serba relatif, berubah-ubah seiring dengan perkembangan zamandan bersifat temporal.Peranan Agama disingkirkan dalam kehidupan, otoritas nalar sangat diagung-agungkan karena ia dianggap sebagai sebuah pilihan yang sangat rasional untuk diikuti.

\section{Penutup}

Permasalahan globalisasi hendaknya disikapi secara proporsional karena ini adalah sikap yang baik sebagai cerminan danmanhaj Islam yangmoderat. Yusuf alQaradhawi menegaskan,umat Islam semestinya mempunyai wawasan luas dan terbuka, banggaterhadap identitasnya, paham tentang risalahnya, dan memegang teguh akan keorisinalitas kitab sucinya. la tidak menghindar dari hal-hal yang baru dan tidak pula menerimanya secara berlebihan. ${ }^{35}$

Tentu kita dapat memilah dan memilih mana yang dianggap baik dan sesuai dengan ajaran Islam dan mana yang tidak sesuai.Terhadap pengaruh yang baik, dengan senang hati dapatlah diterima bahkan jika memungkinkan dapat dikembangkan agar mendapatkan manfaat yang lebih baik.Di samping itu juga, hendaknya adanya keseimbangan dan keharmonisasian antara urusanagama dan dunia.Boleh saja seseorang mengatakan bahwa sistem sosial yang ada telah mengalami perubahan bentuk karena pengaruh global dari negara-negara yang memegang kendali dan terjadi proses penyeragaman bentuk-bentuk sistem sosial di dunia seperti budaya, sistem ekonomi dan politik dengan sistem yang dipraktekkan di

\footnotetext{
${ }^{34}$ Adian Husaini, Wajah Peradaban Barat, 334-7.

${ }^{35}$ Yusuf Qardhawi, al-Muslimūn wa al-'Aulamah (Islam dan Globalisasi Dunia), diterjemahkan oleh Nabhani Idris, (Jakarta: Pustaka al-Kautsar, 2001), 139.
} 
Barat. Namun harus diakui pula bahwa Agama dan sistem kepercayaannya adalah bagian yang tidak mudah mengalami proses tersebut. 


\section{DAFTAR PUSTAKA}

'Abd Al- Bāqī, M. Fuad. 1436 H. al-Mu'jam al-Mufahras li Alfazh al-Qur'ān. Cairo: Dār al- Hadīts.

Afif, Faisal. 2012. Agama dan Globalisasi. Rangkaian Kolom Kluster I Binus University.

Al-Attas, Syed Muhammad Naquib. 1993. Islam and Secularism. Kuala Lumpur: ISTAC.

1995. Prolegomena to The Metaphysic Of Islam.Kuala Lumpur: ISTAC.

Al-Fairūzābādī, Al-Qāmus Al-Muhịț.

Al-Iṣfahānī, Al-Rāghib.Mufradāt li Alfāzh al-Qur'ān.

Beyer, Peter (ed.). 2007. Religion, Globalization, and Culture. Leiden: Koninklijke Brill.

Effendi, Tajuddin Noer. 2003. Globalisasi dan Kemiskinan, dalam Jurnal IImu Sosial dan IImu Politik, Vol. 7, No. 2, Nopember.

Giddens, Anthony. 2000. Jalan Ketiga: Pembaharuan Demokrasi Sosial (Terjemahan). Jakarta: Gramedia.

Hadi, Mukhtar Hadi. Agama di Tengah Arus Globalisasi: Sebuah Pendekatan Multikultural. STAIN Jurai Siwo Metro.

Husaini, Adian. 2014. Wajah Peradaban Barat: Dari Hegemoni Kristen ke Dominasi Sekular-Liberal. Jakarta: Gema Insani.

Ibn Katsīr, Tafsīr Ibn Katsīr. 1999. ed. Sāmī bin Muhammad Salāmah. Cairo: Dār Thayyibah.

Ibn Manẓūr. Tanpa Tahun. Lisān al-'Arab.ed. Abd Allāh Alī al-kabīr. Cairo: Dār alMa'ārif. 
Irsyadunnas. 2005. Konsep Islam Tentang Dunia dan Dinamika Kehidupan, dalam Jurnal Penelitian Agama, Vol. XIV, No. 3.

Khatimah, Khusnul. 2009. Islam dan Globalisasi: Sebuah Pandangan Tentang Universalitas Islam. Komunika (Jurnal Dakwah dan Komunikasi).Vol. 3, No. 1.

Kurniawan, Syamsul. 2018. Globalisasi, Pendidikan Karakter dan Kearifan Lokal yang Hybrid Islam Pada Orang Melayu Kalimantan Barat, Jurnal Penelitian, Vol. 12, No. 2.

Nata, Abudin. 2003. Kapita Selekta Pendidikan Islam. Bandung: Angkasa.

Natsir, Mohammad. 1998. Kebudayaan Islam dalam Perspektif Sejarah.ed. Endang Saifuddin Anshari. Jakarta: Girimukti Pasaka.

Poedjawijatna. 1980. Pembimbing ke Arah Alam Filsafat. Jakarta: PT. Pembangunan.

Qardhawi, Yusuf. 2001. al-Muslimūn wa al-'Aulamah (Islam dan Globalisasi Dunia). Penj. Nabhani Idris. Jakarta: Pustaka al-Kautsar.

Shihab, M. Quraish. 2005. Logika Agama: Kedudukan Wahyu dan Batas-Batas Akal dalam Islam, khususnya dalam pembahasan Islam dan Akal. Jakarta: Lentera Hati.

Thomas, George M. The Culture and Religious Character of World Society.Di dalam Religion, Globalization, and Culture. 